\title{
Art as an instrument to learn how to overcome uncertainty
}

\author{
Uncertainty is an uncomfortable position. \\ But certainty is an absurd one.
}

Voltaire (1694 - 1778)

We continue with our series of articles regarding art as an educational tool in medicine. Our objective was to introduce art as a teaching resource in health care professional training, and our proposal was based on the ability of art's symbolic language to reflect the human dimension of indescribability. ${ }^{1}$

In this article, we will analyze another fundamental aspect of medical practice that may be understood in greater depth through art: the nature of uncertainty and how to manage it. Uncertainty is the lack of certainty which is inherent to the fate of life, and obviously medical practice cannot escape from it. It should not be confused with mere doubt, because doubt entails a lack of action based on fear of the unknown, while uncertainty implies assessing the situation and choosing the most favorable option, even knowing that unexpected events may occur, but deciding to manage them through a continuous re-assessment of the situation and re-adjusting the originally planned course of action. Health care providers also have the task of helping patients channel their uncertainty, and they may do so only once they have managed to handle their own uncertainty. ${ }^{2-5}$

In addition, it is understandable that if incompleteness affects the ideal mathematical world (Gödel) and uncertainty affects the tiny quantum world (Heisenberg), uncertainty will definitively permeate our highly complex (chaotic) supra-atomic world. ${ }^{6}$

Art allows to describe these concepts very clearly. For example, the poem titled Of everything, three things remained by the outstanding writer Fernando Sabino. ${ }^{7}$ In his poem, the author not only describes the unyielding and everlasting presence of uncertainty in our lives, he also discusses the formula to manage it: a blending of patience, acceptance and willingness to start over and over again. Let us take a look at the poem:

Of everything, three things remained:

The certainty that we were always starting again.

The certainty that we had to go on.

The certainty that we will be interrupted before we had finished.

Build a new path out of the interruption; a dancing step, out of the fall; a ladder, out of fear; a bridge, out of dreams; an encounter, out of the quest.

To sum up, introducing art as an educational tool is highly valuable and will allow to better understand the nature of uncertainty and how health care providers may be able to manage it.

Carlos G. Musso, M.D. and Paula A. Enz, M.D. School of Medicine, Instituto Universitario del Hospital Italiano de Buenos Aires. Argentina

http:/ /dx.doi.org/10.5546/aap.2015.eng.485

\section{REFERENCES}

1. Musso CG, Enz PA. El arte como instrumento educativo en medicina. Arch Argent Pediatr 2014;112(6):494-5.

2. Castaneda C. La rueda del tiempo: los chamales del antiguo México y sus pensamientos acerca de la vida, la muerte y el universo. Madrid: Gaia; 1998.

3. Ferry L. La sabiduría de los mitos: aprender a vivir. Buenos Aires: Taurus; 2010.

4. Musso CG, Enz P. Arte y naturaleza humana VII. Rev Hospital B. Aires 2012;32:(1).

5. Musso CG, Enz P. Arte y naturaleza humana X. Rev Hospital B. Aires 2012;32(4):194-5.

6. Musso CG. Obras maestras del arte universal y la medicina: Muerte y hombre (Los autovidentes II) de Egon Schiele (18901918). Evid actual práct ambul. (En prensa) 2015.

7. Sabino F. Encuentro marcado. Barcelona: Luis de Caralt, 1964. 


\section{Humanism and scientific rigor: twins separated at birth}

Humanism in medicine and scientific rigor are supplementary, not incompatible, especially in our profession. I am sure every physician, regardless of their age or years of practice, will agree with me. However, they probably also practice them in an unbalanced manner.

Seeking refuge in dogmatic scientism is probably based on ignorance regarding the importance of values regulating physicians' behavior but also, or mainly, on ignorance regarding how to embrace such values. How can humanistic knowledge be provided and translated into actual skills when dealing with patients and colleagues? Several institutions make heroic efforts to provide the necessary environment and time to prevent burnout syndrome. Many proposed activities are based on a more humanized medical practice. ${ }^{1}$

Sooner or later, the balance of practice tilts to the pan of scientific training and know-how gathering. However, medical success is sought simply using the tools at hand, which are not necessarily the best tools. Continuous training, participating in academic life, considering new practices, developing critical thinking, etc., are necessary but not enough for successful medical care (not for a comprehensive success that includes full satisfaction of physicians with themselves as human beings, not just with the technical work they do).

Studies have emerged demonstrating what folk wisdom has always been stating: success is not the key to happiness, ${ }^{3}$ at the same time, a greater happiness leads to being more effective and responsible for tasks performed. For this reason, investments are being made to provide workers with compensations aimed at increasing their happiness. Anyhow, my prediction is that soon it will be demonstrated that any external factor provided (and that in our profession works as a protection against burnout) will not be enough, because happiness does not depend on what you have but on what you are. Such being requires investment so that joy and satisfaction with oneself become the basis for a job that balances humanism and scientific knowledge.

Empathy, the capacity to give affection and esteem are invaluable when seeing patients and their families. Controlling setbacks or discomforts, being able to have an actual commitment with patients without completely or inadequately undermining your attitude are also elements for internal and external success that provide us with satisfaction and comfort. These and other skills that are not specifically related to solving medical problems may help us feel good before, during and after a visit with patients and their parents.

Our human nature gets unbalanced when we focus on just one aspect while seeing a patient. Our practice requires both a humanistic approach and scientific rigor. An unbalanced medical care is detrimental to us and to our patients, but how can we improve as human beings? Where do we forge the balance we are looking for? In the mind. Training our mind is essential for the systematic, consistent and harmonious development of humanism in ourselves. It has been presented as a desideratum for a very long time, as recalled by Daniel Siegel, pediatrician and psychiatrist: "More than 100 years ago, the father of modern psychology, Williams James (1890-1981), said that the capability to rechannel digressive attention over and over again would be 'education par excellence'. He also said that we do not know how to do it." 3 Advances have been made since then. Different disciplines have provided answers in this regard, including one from Argentina: Logosophy. In 1956, Doctor Friedenthal, who had practiced logosophy from a very young age, wrote: "Knowledge translated into the art of healing undoubtedly has to go through the psychological structure of the person applying it. There, in that intimate and deep contact where science and personality fit together, knowledge is both beneficially and negatively influenced, and its most noble essence may even lose its nature(...). Therefore, every professional of the art of healing should be a zealous defender of the health of their own souls, because society has conferred a very high level of responsibility upon them, which they should consciously manage if they want to enjoy actual spiritual tranquility." 4 Information and medical training converge in the mind of physicians; that is also where values and virtues that allow a more human practice may also develop.

Progressing towards making the mind respond to our own objectives and goals (instead of responding automatically and, many times, contrary to our deepest purposes) is essential to turn high standards of behavior into a systemic, not random, reality. This is scarcely a portion of the comprehensive development process 
that we could face. This consistent process of self-improvement (consistent because it refers to a persistent effort, not because all attempts are successful...) implies advancing in the development of a new humanism that consists of "a rational and conscious being capable of achieving within himself the excellence of the human condition and his spiritual dimension based on an unceasing improvement. Such excellence qualities should be translated into examples and teaching for mankind." ${ }^{5}$ As mentioned above, any resource we use to achieve a more conscious lifestyle will lead us to become more rigorous in relation to acquiring scientific knowledge and our desire to further get trained in this field. A lifestyle along which we could daily work against our negative modalities, learning to let the joy of being alive emerge from us, having the acquisition of superior knowledge as our daily goal, feeling satisfied with helping our fellow men.

As I see it, in medicine, scientific rigor and humanism share the same "genetic" elements: do good, heal, relieve. However, as what may occur with twins, these two aspects may take different paths that lead them to dogmatism and lack of communication between one another. The ability to find tools to reconcile them is within ourselves, so that there is union where there was separation.
One of the best tools is self-knowledge and the resulting improvement.

To paraphrase Doctor Escardó: you cannot be a better physician than what you are as a person. Thus, practicing a discipline to improve ourselves as human beings will also make us better physicians. The statement proposed by the Argentine Society of Pediatrics, "a healthy child in a better world", may become a reality by improving the most intimate part of the world: ourselves.

\section{Paula A. Pradines, M.D.}

Sanatorio "Franchin"

pradines.paula@gmail.com

http:/ /dx.doi.org/10.5546/aap.2015.eng.486

\section{REFERENCES}

1. Catsicaris C, Eymann A, Cacchiarelli N. Usandivaras I. La persona del médico residente y el síndrome de desgaste profesional (burnout). Un modelo de prevención en la formación médica. Arch Argent Pediatr 2007;105(3):236-40/36.

2. Gilbert DT. Ordinary personology. In: Gilbert D., Fiske S., Lindzey G. (Eds.). The handbook of social psychology. 4th ed. Vol 2. New York: Random House; 1998:89-150.

3. Siegel DJ. Mainfulness y psicoterapia. Barcelona: Paidos 2012:55.

4. Friedenthal M. Psicología para los profesionales del arte de curar. $2^{\circ}$ ed. Buenos Aires: Progental, 1956.p.3.

5. González Pecotche CB. Mecanismo de la vida consciente. $7^{\circ}$ ed. Buenos Aires: Logosófica. 2014:106.

\section{Lung development in children and its relationship to environmental pollution}

Environmental pollution causes different harmful effects on health, and affects mainly the respiratory system. In general, in densely populated, industrial cities, the environment becomes corrupted due to the increased production of pollutants resulting from engine combustion, from both vehicles and large factories.

Living in a city with a high level of environmental pollution leads inhabitants to inhale airborne particles of different sizes, causing a great number of diseases, especially of respiratory nature. Children sustain a continuous growth and development and are not exempt from being affected by such external noxious agents that may cause different respiratory symptoms and affect the normal development of their lungs. Growing urban developments go hand in hand with increasing environmental pollution, causing an exponential increase in asthma and asthma exacerbations. In a study conducted among children with asthma in 10 European cities, $15 \%$ of asthma exacerbation cases were related to near-roadway traffic pollution. ${ }^{8}$

Pulmonary alterations are caused by direct and indirect mechanisms of action. In countries with very large cities, such as China, environmental particles have a direct effect on the respiratory epithelium and airway neuroreceptors, resulting in irritation and inflammation. In developed countries, where policies have been implemented to control environmental pollution and where pollutant levels are lower, environmental particles are fine and ultrafine and may cause 
inflammation (ozone, nitrogen dioxide, and particulate matter $[\mathrm{PM}]<2.5$ ), while others cause hypereactivity (ozone and nitrogen dioxide); both of these being components of bronchial asthma. ${ }^{10,11}$ All these particles have also been associated with the development of oxidative stress which is a characteristic of severe asthma, although its mechanism is yet unclear. ${ }^{12}$

Gauderman W. J., et al. assessed whether there was an association between breathing air quality and lung development among children from several cities in southern California (United States of America). ${ }^{1}$ In the past decades, California has implemented drastic environmental pollution control policies in order to reduce environmental pollution and improve environmental quality. They assessed pulmonary function using yearly spirometries performed on 2120 children aged between 11 and 15 years old from three separate cohorts: 1994-1998, 1997-2001 and 2007-2011. They followed 4-year growth in forced expiratory volume in 1 second $\left(\mathrm{FEV}_{1}\right)$ and vital forced capacity (FVC) and established an association with declining environmental pollution levels. ${ }^{1}$

During the four-year period when the three cohorts were assessed, improvements in 4-year growth of FEV and FVC were observed with declining levels of nitrogen dioxide and of particulate matter with an aerodynamic diameter of $2,5 \mu \mathrm{m}$ and $10 \mu \mathrm{m}$. Such improvement in pulmonary function was observed both in males and females, and in asthma patients and nonasthmatic individuals. This association was more significant with increased $\mathrm{FEV}_{1}(91.4 \mathrm{~mL})$ over the four-year period in relation to declining levels of nitrogen dioxide $(14.1 \mathrm{ppb}) p<0.0001$, but this was not observed with reduced ozone. The rate of children with low pulmonary function $(<80 \%$ of predicted values for $\mathrm{FEV}_{1}$ and $\mathrm{FVC}$ ) was clearly lower in the 2007-2011 cohort (3.6\%), which sustained a reduced exposure to environmental pollutants when compared to the other two cohorts $(7.9 \%$ and $6.3 \%$, respectively).

In children, lungs develop at a very fast rate since birth and during the first 6-8 months of life. This process continues to have relevance until 2 years old, when it remarkably slows down, although the number of alveoli keeps increasing until 8-10 years old. Then, with somatic development of adolescents, lung size increases but without a rise in the number of alveoli. ${ }^{2,3}$

This study was based on a successful policy implemented by California (USA) to reduce environmental pollution and observed an improvement in pulmonary function in groups of adolescents from different cities in southern California after adjusting analyzed data for different potential confounders, but there was no control group from a community where such policy had not been implemented. Adolescents' lungs increase in size due to the somatic development typical of their age, many times accompanied by vigorous physical activity, which also improves their aerobic capacity. A control group with adolescents would ensure that improvements observed in pulmonary function are caused by reduced levels of environmental pollution and not by a normal lung and somatic development. In spite of this, and having observed an increase in pulmonary function at 15 years old when compared to baseline pulmonary function measured at 11 years old in each cohort, the 2007-2011 cohort, which was exposed to a lower level of environmental pollution (pollution had markedly declined in this period as compared to the previously assessed cohorts), showed an improvement in baseline pulmonary function as well as a lower number of adolescents with a baseline pulmonary function ( $\mathrm{FEV}_{1}$ and $\left.\mathrm{FVC}\right)$ lower than $80 \%$; all this makes us infer that the policy implemented by California had a positive effect on the reduction of environmental pollutants and an improvement in breathing air quality, leading to an improvement in lung development and growth of exposed children. This study found no association with exposure to ozone, which has been shown to have a positive association with respiratory disease mortality in patients exposed to higher levels of ozone in a recent study conducted by the Centers for Disease Control and Prevention (CDC). ${ }^{4}$

The impact of high levels of environmental pollution on respiratory health of continuously growing children affects lung development and increases morbidity due to different pulmonary diseases. As can be clearly seen, these few studies and government policies on environmental pollutant emission have substantially improved lung development in children and reduced respiratory diseases. In a world that is in continuous development, with an increased number of industries and vehicle traffic volume as the main causes of environmental pollution, it is possible to maintain an adequate control of pollutant emission so to allow our children to grow and develop healthily. 
Conrado J. Llapur, M.D. Hospital del Niño Jesús de Tucumán School of Medicine of Universidad Nacional de Tucumán, Argentina.

http:/ /dx.doi.org/10.5546/aap.2015.eng.487

\section{REFERENCES}

1. Gauderman WJ, Urman R, Avol E, Berhane K, et al. Association of improved air quality with lung development in children. N Engl J Med 2015;372(10):905-13.

2. Hislop AA, Wigglesworth JS, Desai R. Alveolar development in the human fetus and infant. Early Hum Dev 1986;13(1):1-11.

3. Hislop A, Reid L. Development of the acinus in the human lung. Thorax 1974;29(1):90-4.

4. Hao Y, Balluz L, Strosnider H, Wen XJ, Li C, Qualters JR. Ozone, Fine Particulate Matter and Chronic Lower Respiratory Disease Mortality in the United States. Am J Respir Crit Care Med 2015; May 27. [Epub ahead of print]

5. Gauderman WJ, Avol E, Gilliland F, Vora H, et al. The effect of air pollution on lung development from 10 to 18 years of age. N Engl J Med 2004;351(11):1057-67.
6. ElliotJ,Vullermin P, Robinson P. Maternal cigarette smoking is associated with increased inner airway wall thickness in children who die from sudden infant death syndrome. Am J Respir Crit Care Med 1998;158(3):802-6.

7. Tepper RS, Williams-Nkomo T, Martinez T, Kisling J, et al. Parental smoking and airway reactivity in healthy infants. Am J Respir Crit Care Med. 2005;171(1):78-82.

8. Perez L, Declercq C, Iñiguez C, Aguilera I, et al. Chronic burden of near-roadway traffic pollution in 10 European cities (APHEKOMnetwork). Eur Respir J2013;42(3):594-605.

9. Brunst KJ, Ryan PH, Brokamp C, Bernstein D, et al. Timing and Duration of Traffic-Related Air Pollution Exposure and the Risk for Childhood Wheeze and Asthma. Am J Respir Crit Care Med 2015 Jun 24. [Epub ahead of print]

10. Aris RM, Christian D, Hearne PQ, Kerr K, et al. Ozoneinduced airway inflammation in human subjects as determined by airway lavage and biopsy. Am Rev Respir Dis 1993;148(5):1363-72.

11. Solomon C, Christian DL, Chen LL, Welch BS, et al. Effect of serial-day exposure to nitrogen dioxide on airway and blood leukocytes and lymphocyte subsets. Eur Respir 2000;15(5):922-8.

12. Liu L, Poon R, Chen L, Frescura AM, et al. Acute effects of air pollution on pulmonary function, airway inflammation, and oxidative stress in asthmatic children. Environ Health Perspect 2009;117(4):668-74. 